\section{PENELITIAN PENGARUH NAPHTHENIC OIL DAN HAF BLACK TERHADAP SIFAT PAMPAT TETAP PADA KOMPON LIS KACA MOBIL}

Oleh : Abuchori, Asrilah, Sri Brataningsih Puji Lestari

\section{ABSTRACT}

The objective of the research is to know the influence of naphthenic oil and HAF black properties of the compression set by constant load and constant deflection rubber strip compound. Rubber strip compound is made from natural rubber (RSS) and synthetic rubber (SBR 1502) with the addition of ingredient such as softener, activator, filler, anti oxidant, accelerator and vulacanizing agent. It should be carried out using base formula by varrying naphthenic oil $3 ; 5$ and 7 parts and carbon black $45 ; 50$ and 55 parts for 9 compounds, then it should be tested their physical properties, compression set by constant load and constant deflection. The test is actually able to fullfill the specification of SII 1999-86 "Lis karet kaca kendaraan bermotor". The result of the test statistically prove that naphthenicc oil and HAF black influence the physical properties.

\section{INTISARI}

Penelitian ini bertujuan untuk mengetahui pengaruh naphthenic oil dan HAF black terhadap sifat pampat tetap dengan constant load dan constant deflextion kompon lis kaca mobil. Lis kaca mobil dibuat dari campuran bahan baku karet alam RSS) dan karet sintetik (SBR 1502) dengan ditambahkan bahan-bahan pembantu (ingridient) seperti bahan pelunak, pengaktif, pengisi, anti oksidant, pencepat dan ats pemvulkanisasi. dengan formula dasar dibuat kompon lis kaca mobil dengan memvariasikan bagian naphthenic oil : $3 ; 5$ dan 7 bagian serta carbon black : $45 ; 50$ dan 55 bagian. Didapat 9 kompon dan diuji sifat-sifat fisis pampat tetap menggunakan constant load dan constant deflextion, hasil uji memenuhi persyaratan SII 1999-86 "Lis kaca kendaraan bermotor". Perhitungan statistik menunjukkan bahwa naphthenic oil dan carbon black berpengaruh terhadap sifat fisis yang diuji.

\section{PENDAHULUAN}

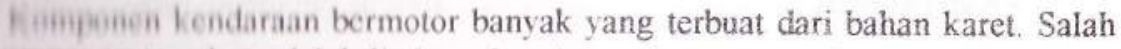

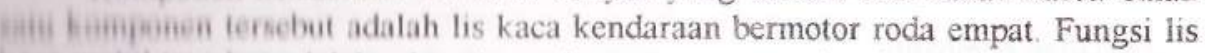

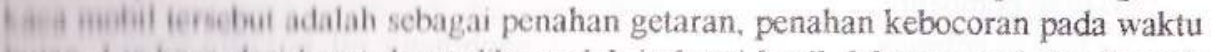
hinain I in hise dari karet dapat dibuat oleh industri kecil dalam negeri dan banyak I Initif dipanaran dengan kualitas yang sangat bervariasi. Dari kualitas yang (IIHihini ini didapatkan hasil uji pampat tetap yang tidak memenuhi persyaratan (1) I hiak ia maka perlu dilakukan penelitian untuk mendapatkan kompon lis kaca Initii yang memenuhi persyaratan.

What sifit barang karet tergantung pada sifat dasar dan jumlah filler yang ifinitihion. hal ini merupakan prinsip dasar yang umum untuk mencapai P Ifyitaian mutu beberapa barang karet. Kenyataan bahwa perkiraan terhadap yinhit hime ditentukan dari beaya terhadap volume fillernya bukan beaya berat (iliening $(2)$

(I)ip pembuatan barang karet harus didahului dengan membuat kompon yang iin Hiemihi pesyaratan barang karet tersebut. Untuk lis kaca komponnya harus Heinhin if hemampuan ckstruksi yang sangat baik, viskositas yang sangat rendah dari

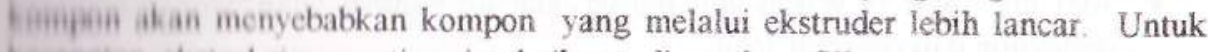
Hu yitin okstruksi yang tinggi sebaiknya digunakan filler yang mutunya tinggi 4ivil ili black dan penguat china clay (4). Bila carbon black yang digunakan hiaini filier dengan mutu rendah mungkin akan didapatkan barang-barang Hiliihyi yang lunak dan tidak stabil bentuknya. Untuk kecepatan ekstruksi dan hiati athir yang baik maka jika digunakan filler yang mutunya tinggi lebih baik Heinakan naphthenic oil atau aromatic oil.

Mengingat pentingnya fungsi naphthenic oil dan carbon black terhadap sifat Hifin turing barang karet, maka dicoba melakukan penelitian pengaruh naphthenic nif diit cubon black terhadap pampat tetap dengan constant load maupun constant iflituton untuk meningkatkan mutu kompon lis kaca mobil agar memenuhi

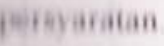

\section{MATERI DAN METODE PENELITIAN}

\section{Materi}

Materi penelitian berupa bahan baku, bahan pembantu, dan peralatan yang digunakan dalam penelitian. 
a. Bahan baku

- Karet alam

- Karet sintetis

rubber smoked sheet (RSS I)

styrene butadiene rubber (SBR 1502)

b. Bahan pembantu

- Bahan pelunak

- Bahan pengaktif

- Bahan pencepat

- Bahan pengisi

- Anti oksidan

- Zat pemvulkanisasi

- Memperbaikai

kenampakan

c. Peralatan

- Pembuat kompon : timbangan, pisau potong, krus porselin, two roll mill. cetakan kompon (bentuk slab), hydraulic press, stopwach, lembaran aluminium foil

- Alat uji : Alat iji waktu vulkanisasi, alat uji pampat tetap dengan constant deflextion dan constant load.

2. Metode penelitian

a. formulasi kompon

\begin{tabular}{|l|l|l|c|}
\hline Bahan & Bagian berat & \multicolumn{1}{|c|}{ Bahan } & $\begin{array}{c}\text { Bagian } \\
\text { berat }\end{array}$ \\
\hline RSS I & 75 & Asam stearat & 1,5 \\
SBR 1502 & 25 & Santocure CBS & 1,2 \\
Napththenic oil & $3: 5 ; 7$ & T M T D & 0,2 \\
HAF Black & $45 ; 50,55$ & AOSP & 1 \\
CaCO3 & 10 & Paraffin wax & 1 \\
Factice oil & 2,5 & Sulphur & 2 \\
ZnO & 4 & & \\
\hline
\end{tabular}

b. Proses pembuatan kompon lis kaca mobil

- Bahan ditimbang sesuai kebutuhan

- Karet alam (RSS) digiling dalam two roll mill kemudian ditambahn SBR 1502. digiling sampai plastis. Suhu two roll mill dijaga paling tinggi $70^{\circ} \mathrm{C}$
Hite lahi plastis ditambahkan secara berurutan paraffin wax. $\mathrm{ZnO}$. Asam tharai AOSP, factice oil $\mathrm{CaCO}_{3}$. naphthaneic oil dan HAF Black. fifiling sampai homogen, kemudian santocure CBS. TMTD

ferah his tambahkan sulphur digiling sampai homogen.

I ниям⿱亠䒑 yang sudah jadi disimpan dalam ruang conditioning selama 24 finit

He tiahi itu dilakukan uji curetime untuk mengetahui waktu optimum

hemanikan kompon pada suhu $150^{\circ} \mathrm{C}$

( th hanin $150 \mathrm{~kg} / \mathrm{cm}^{2}$ dan waktu sesuai hasil uji curetime.

\section{Whengician}

I hmipoin vang telah dibuat dikondisikan dalam ruang kondisi dengan suhu 114i helama 24 jam, selanjutnya dibuat contoh uji pampat tetap. kemudian Hitii pampat tetap

Theniinim pampat tetap sesuai SIl 1999-86, Lis Karet kaca kendaraan In remeter

Alit in uguian pampat tetap ada dua macam yaitu

Alit dengan metode pampat tetap ( constant deflextion)

Alit dengan metode pembebanan tetap (constant load)

Thiоними uii berbentuk silinder dengan ukuran $30 \mathrm{~mm}$ dan tinggi/ tebal 15 iini. ie hadap contoh karet yang kekerasannya 65-84 shore A. maka in mampatan $25 \%$ dari tebal contoh.

if Analisin datu

Thiti data hasil pengujian dianalisa secara statistik dengan menggunakan melente factorial

\section{IIASIL PENELITIAN DAN PEMBAHASAN}

Ilisil penelitian berupa data hasil uji dan hasil perhitungan statistik (ANOVA) (i) fнінің tetap tetap menggunakan alat constant deflection dan constant load. Data

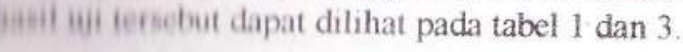


Tabel 1. : Hasil uji pampat tetap dengan constant deflextion (\%).

\begin{tabular}{|c|c|c|c|c|c|}
\hline \multirow{2}{*}{$\begin{array}{c}\text { Naphthenic } \\
\text { oil }\end{array}$} & \multirow{2}{*}{$\begin{array}{c}\text { Carbon } \\
\text { Black }\end{array}$} & \multicolumn{3}{|c|}{ U I a n g a n } & \multirow{2}{*}{ Rata-rata } \\
\cline { 3 - 5 } & & 1 & 2 & 3 & \\
\hline \multirow{3}{*}{3} & 45 & 37,26 & 35,26 & 32,57 & 35,06 \\
& 50 & 30,14 & 34,37 & 34,37 & 32,96 \\
& 55 & 36,24 & 34,82 & 39,22 & 36,76 \\
\hline 5 & 45 & 23,81 & 24,33 & 29,44 & 25,86 \\
& 50 & 25,55 & 29,06 & 27,03 & 27,21 \\
& 55 & 30,28 & 31,42 & 32,39 & 31,36 \\
\hline 7 & 45 & 23,99 & 25,00 & 24,80 & 24,60 \\
& 50 & 32,79 & 25,24 & 25,24 & 27,25 \\
& 55 & 30,71 & 28,50 & 28,00 & 29,07 \\
\hline
\end{tabular}

Hasil perhitungan statistik untuk uji pampat tetap dengan alat constant deflecti terihhat pada tabel 2 .

Tabel 2. : Analisa Sidik Ragam (ANOVA) untuk pampat tetap dengan constant deflection.

\begin{tabular}{|c|c|c|c|c|c|c|}
\hline \multirow[t]{2}{*}{ Sumber variasi } & \multirow[t]{2}{*}{$\mathrm{dk}$} & \multirow[t]{2}{*}{ JK } & \multirow[t]{2}{*}{ RJK } & \multirow[t]{2}{*}{ F Hitung } & \multicolumn{2}{|c|}{ F tabel } \\
\hline & & & & & $5 \%$ & $1 \%$ \\
\hline Ulangan & 2 & 1,6518 & 0,8259 & & & \\
\hline Perlakuan & 8 & 598,7709 & 74,8464 & & & \\
\hline Naphthenic Oil & 2 & 495,7335 & 247,8668 & $36,3900 * *$ & 3,63 & 6,23 \\
\hline Carbon Black & 2 & 3,4314 & $\cdot 1,7157$ & 0,2519 & 3,63 & 6,23 \\
\hline $\begin{array}{l}\text { Interaksi Naphthenic } \\
\text { Oi] X Carbon Black }\end{array}$ & 4 & 99,6060 & 24,9015 & $3.6561^{*}$ & 301 & 4.77 \\
\hline Kekeliruan & 16 & 108,9740 & 6,8109 & & & \\
\hline Tota 1 & 26 & 709,3968 & & & & \\
\hline
\end{tabular}

** ada beda sangat nyata

Dengan perhitungan MDRS $=\mathrm{rp} \mathrm{xs}=1,506$ diperoleh interaksi naphthenic o carbon black terbaik adalah naphthenic oil 7 bagian dengan carbon black 45 bagi fitis I Ifanil uii pampat tetap dengan constant load

\begin{tabular}{|c|c|c|c|c|c|}
\hline \multirow{2}{*}{$\begin{array}{c}\text { Pathighenie } \\
\text { nil }\end{array}$} & \multirow{2}{*}{$\begin{array}{l}\text { Carbon } \\
\text { Black }\end{array}$} & \multicolumn{3}{|c|}{ Ulangan } & \multirow{2}{*}{ Rata-rata } \\
\hline & & 1 & 2 & 3 & \\
\hline 1 & $\begin{array}{l}45 \\
50 \\
55 \\
\end{array}$ & $\begin{array}{l}8,18 \\
9,97 \\
8,78\end{array}$ & $\begin{array}{l}5,41 \\
9,91 \\
6,36\end{array}$ & $\begin{array}{l}5,73 \\
7,95 \\
9,49\end{array}$ & $\begin{array}{l}6,35 \\
9,28 \\
8,21 \\
\end{array}$ \\
\hline i & $\begin{array}{l}45 \\
50 \\
55 \\
\end{array}$ & $\begin{array}{l}5,43 \\
9,36 \\
7,32 \\
\end{array}$ & $\begin{array}{l}6,52 \\
6.52 \\
7,72 \\
\end{array}$ & $\begin{array}{l}6,66 \\
7,50 \\
7,92\end{array}$ & $\begin{array}{l}6,20 \\
7,79 \\
7,65\end{array}$ \\
\hline$?$ & $\begin{array}{l}45 \\
50 \\
55\end{array}$ & $\begin{array}{l}6,52 \\
7,40 \\
4,54 \\
\end{array}$ & $\begin{array}{l}5,62 \\
7,55 \\
5,87\end{array}$ & $\begin{array}{l}5,59 \\
7,99 \\
6,02\end{array}$ & $\begin{array}{l}5,91 \\
7,65 \\
6,99 \\
\end{array}$ \\
\hline
\end{tabular}

Iiwil jurhifungan statistik uji pampat tetap dengan alat consiant load dituangkan baitini lentak tabel 4

Iitul I Analisa Sidik Ragam (ANOVA) untuk pampat tetap dengan constant load

\begin{tabular}{|c|c|c|c|c|c|c|}
\hline \multirow[t]{2}{*}{ finilier variasi } & \multirow[t]{2}{*}{$\mathrm{dk}$} & \multirow[t]{2}{*}{ JK } & \multirow[t]{2}{*}{ RJK } & \multirow[t]{2}{*}{ F Hitung } & \multicolumn{2}{|c|}{ E tabel } \\
\hline & & & & & $5 \%$ & $1 \%$ \\
\hline Thingenin & 2 & 2,0229 & 1,0114 & & & \\
\hline 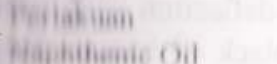 & 8 & 47,4052 & 5,9256 & & & \\
\hline 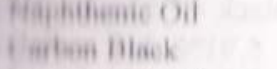 & $\begin{array}{l}2 \\
2\end{array}$ & $\begin{array}{l}14,2049 \\
22,5046\end{array}$ & $\begin{array}{r}7,1024 \\
11.2523\end{array}$ & $\begin{array}{l}9,1893^{* *} \\
145585 \text { * }\end{array}$ & 3,63 & $\begin{array}{l}6,23 \\
6,23\end{array}$ \\
\hline linierakin Naphthenic & & & & 14,500, & 3,63 & \\
\hline (ii) X Carbon Black & 4 & 10,6957 & 2,6737 & $3,4595^{*}$ & 3,01 & 4,77 \\
\hline fiteliniken & 16 & 12,3667 & 0,7729 & & & \\
\hline 10131 & 26 & & & & & \\
\hline
\end{tabular}

inia boda sangat nyata.

(Aengan perhitungan MDRS $=\mathrm{rp} x \mathrm{sx}$, dimana $\mathrm{sx}=0,5076$, diperoleh interaksi tithaik adalah kompon dengan naphthenic oil 7 bagian dan carbon black 45 bagian densan nilai $5,91 \%$.

Tyigujian pampat tetap kompon lis kaca mobil untuk menentukan perubahan tebal Hiitii contoh karet jika ditekan selama beberapa waktu. Pengujian ini perlu untuk mенguji karet packing, landasan mesin, lis kaca dan sebagainya. 
Sifat pampat tetap pada lis karet kaca mobil berpengaruh langsung terhadap kaca pada bingkai badan mobil, oleh karena itu apabila sifat pampat tetap tidak baik (tidak memenuhi persyaratan standar) menyebabkan kaca mudah kendur

Hasil uji pampat tetap menggunakan constant load maupun constant deflection menunjukkan bahwa : semakin banyak naphthenic oil yang digunakan dalam batas tertentu akan memperbaiki pampat tetap, karena penggunaan naphthenic oil dalan karet akan menarmbah kekenyalan, sedangkan pengaruh filler carbon black sernaki banyak, hasil uji pampat tetap semakin rendah.

Dari tabel 2 dapat dilihat bahwa hasil uji pampat tetap dengan constan deflection dipengaruhi oleh interaksi antara naphthenic oil dan carbon black Kompon dengan naphthenic oil 7 bagian dengan carbon black 45 bagia menghasilkan pampat tetap dengan constant deflection yang terkecil atau terbaik.

Hasil pampat tetap dengan alat uji constant load juga dipengaruhi oleh interak naphthenic oil dengan carbon black. Interaksi terbaik adalah kompon denga naphthenic oil 7 bagian dengan carbon black 45 bagian dengan nilai $5.91^{\circ}$ (tabel 4)

\section{KESIMPULAN}

1. Dari perhitungan hasil uji statistik dapat disimpulkan bahwa hasil uji pamp tetap menggunakan alat constant load maupun constant deflection yang terbai adalah dengan naphthenic oil 7 bagian dengan carbon black 45 bagian denga nilai untuk pampat tetap dengan constant load adalah : 5,91\% dan memenu SII 1999-86 "Lis karet kaca kendaraan bermotor"

2. Menggunakan naphthenic oil dan carbon black pada kompon lis karet kac mobil dalam batas-batas tertentu (pada variasi) dapat disimpulkan bahw semakin banyak naphthenic oil yang ditambahkan akan memperbaiki sif pampat tetap, sedangkan semakin banyak carbon black yang ditambahkan pa kompon lis kaca mobil akan menurunkan sifat uji pampat tetap.

\section{DAFTAR PUSTAKA}

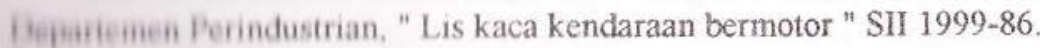

Iitinty Larfun. "Modern rubber chemistry " D. Van Nostrand Inc, New York. IIHA (10H4).

Aiainine Morion. "Rubber Technology ". Reinhald Publishing. Corporation Ihind Printing. New York (1963)

(linail Hishinest. "Publication Rubber Technology and Manufacture"

h Hiniting if "I xperimental Design " Fakultas Technologi Pertanian 